\title{
Farmers' Understanding of Organic Agriculture Practices
}

\author{
Sutawi \\ Universityof Muhammadiyah \\ Malang
}

\author{
Indah Prihartini \\ University of Muhammadiyah \\ Malang
}

\author{
Daroe Iswatiningsih \\ University of Muhammadiyah \\ Malang
}

\begin{abstract}
Organic farming is a new way to increase agricultural production, food security, human and environment health, and empower farmers. This study aims to: (1) Analyze farmers' knowledge of organic farming systems, and (2) Analyze farmer's assessment of organic farming practices. The research was conducted by a survey method on 70 farmer members of Mandiri Farmers Group in Lombok Kulon Village, the location of organic rice farming pilot project in Bondowoso Regency. Farmers' knowledge of organic farming systems shows: (1) $\mathbf{8 8 . 5 7 \%}$ of farmers know that agricultural land must be converted from non-organic to organic without contamination of synthetic chemicals for 2-3 years; (2) $98.57 \%$ of farmers know that organic farming uses organic fertilizer; (3) $72.86 \%$ farmers know that organic farming uses natural variety seeds, not genetically modified seeds; (4) $92.86 \%$ of farmers know that pest and disease control using organic pesticides; and (5) $87.14 \%$ of farmers know that irrigated water and land for organic farming should be separated from conventional farming. Farmers' assessment of the complexity of organic farming practices shows: (1) Agricultural land which should be converted from non-organic soil to organic one without polluted synthetic chemicals for 2-3 years is considered long time by $44.29 \%$ and very long by 24.29\% farmers; (2) The use of organic fertilizer is considered easy by $50 \%$ of farmers; (3) As many as $50 \%$ of all farmers stated that the price of organic seeds is not different from the seeds used by conventional farmers; (4) Control of plant pests and diseases by using organic pesticides is considered more difficult than the control of plant pests and diseases by using synthetic chemical pesticides by $47.14 \%$ of farmers; and (5) A total of $55.71 \%$ of farmers find it difficult and very difficult to separate land and irrigation sources from conventional farming. The results conclude that although most farmers already have knowledge of organic farming systems, there is still difficulty in organic farming practices. This is one of the strong reasons why organic farming practices are not widely adopted by farmers.
\end{abstract}

Key words: organic farming system, organic farming knowledge, organic farming practices.

\section{INTRODUCTION}

Food production in Indonesia over the last four decades is the result of intensification of food crop cultivation that relies on green revolution technology, where crop cultivation is laden with chemical fertilizers and pesticides. The application of green revolution technology to the cultivation of food crops is indeed able to boost, even multiply the production of food crops. On the other hand, green technology is suspected to have side effects on human's health, environmental sustainability, and sustainability of agricultural systems. Pollution of chemical fertilizers, pesticides, medicines, and other factory-made materials due to excessive use, has an impact on the deterioration of environmental quality and human's health. Understanding of the dangers of artificial chemicals in the long term began to realize, so some farmers re-cultivate naturally called organic farming.

Organic farming is defined as a holistic and integrated agricultural production system, by optimizing the health and productivity of agroecosystems naturally, resulting in sufficient, quality, and sustainable food and fiber [1]. According to the CODEX Alimentarius Commission [2], organic farming is the whole production management system that encourages and develops agro-ecosystem health, including biodiversity, biological cycles and soil biological activities. SNI 6729:2016 on Organic Farming System states that Organic Farming System is a holistic production management system to improve and develop agro-ecosystem health, including biodiversity, biological cycle, and soil biological activity [3].

The practice of organic farming according to Sutanto [4] is highly dependent on local 
knowledge of farmers and local agricultural conditions. In general, the most easily measured organic farming practices among farmers include five indicators: (1) conversion of land from inorganic to organic, (2) use of organic fertilizer, (3) use of local natural varieties, (4) pest and disease control plants using organic pesticides, and (5) separation of land and irrigation water sources of organic farming from conventional farming. The practice of organic agriculture is a minimum requirement that must be fulfilled by farmers if they want to be recognized as organic farmers. This is due to organic farming, not only seen from the use of organic fertilizer alone, but many aspects are also assessed, including the attitude of farmers themselves against nature. In addition, an organic farm will be completely free from synthetic chemical residues and able to produce stably and optimally if it has undergone a period of conversion from non organic soil to organic without contamination of synthetic chemicals for at least one year or more.

\section{METHODS}

This study aims to: (1) Analyze farmers' knowledge about organic farming systems, and (2) Analyze farmer's assessment of organic farming practices. The research was conducted by means ofa survey method on 70 farmer members of Mandiri Farmer Group in Lombok Kulon Village, the location of the pilot project of organic rice farming in Bondowoso Regency. Farmers were asked to answer questionnaires about the knowledge and experience of organic farming practices on five indicators based on SNI 6729: 2016, namely: (1) conversion of land from inorganic to organic, (2) use of organic fertilizers, (3) use of natural varieties (local) (4) control of pests and diseases of plants using organic pesticides, and (5) separation of irrigated agricultural land and irrigation resources from conventional farming.

\section{RESULT}

Farmer's Understanding of Organic Farming System

Most of the farmers members of the organic agricultural area program understand about organic farming SNI 6729: 2016. As presented in Table 1 where more than $70 \%$ of farmers know the procedures and requirements of organic farming i.e. agricultural land must be converted from being non-organic to organic without contaminated by synthetic chemicals for 2-3 years, using organic fertilizers - using seeds / natural seed varieties and not genetically engineered / modified; pest and disease control should use organic materials; and land pesticides and irrigation water sources for organic farming should be separated from conventional farming. Even, more than $90 \%$ of farmers have understood that pest control uses organic pesticides or is free of chemical drugs. Farmers have realized that using chemical pesticides poison not only the soil, but also cattle and human plants. The average numbers of farmershaveremoved chemical pesticides and replaced them with organic pesticides. Farmers's understanding is also high where the awareness to use organic fertilizer is more than $90 \%$. And they also understand the good use of organic fertilizers which not only fertilize the plant but also, most importantly, enhance the improvement of soil fertility.

The use of organic fertilizer will increase soil organic matters and will further increase soil microbial populations that play an important role in the biodegradation of chemical residues. In addition, organic compounds of land and soil microbial activity will improve the balance of the land ecosystem and improve the physical and chemical balance of the land. Prior to the implementation of the organic farming program, the soil organic matters in Bondowoso Regency is very low, with approximately only around 2\%; but after the program runs on the demo plot locations (Lombok Kulon, Sulek and Wringin), the content of organic materials, especially in the area and the affected areas, organic matter shows a significant increase as indicated with soil fertility and organic farming. Farmers in the affected plot area recognize and understand that adding organic fertilizers to the soil will improve soil fertility and further improve agricultural production. The land after incorporating organic fertilizersas many as around 10 tons per ha will increase the soil's

organic matter, neutralize $\mathrm{pH}$, increase soil's ecosystem activity and reduce chemical residues and heavy metal poisoning due to the use of pesticides[5]. 
Table 1. Farmers' Knowledge of 5 Main Indicators of Organic Farming

\begin{tabular}{|c|c|c|c|c|}
\hline & Main Indicators & Answer & Amount & Percent \\
\hline 1 & $\begin{array}{l}\text { Farmland must be converted from non- } \\
\text { organic to organic one without } \\
\text { contaminated by synthetic chemicals for } \\
2-3 \text { years }\end{array}$ & $\begin{array}{l}\text { a. Know } \\
\text { b. Do not know }\end{array}$ & $\begin{array}{r}62 \\
8\end{array}$ & $\begin{array}{l}89 \\
11\end{array}$ \\
\hline 2 & Using organic fertilizers & $\begin{array}{l}\text { a. Know } \\
\text { b. Do not know }\end{array}$ & $\begin{array}{r}69 \\
1\end{array}$ & $\begin{array}{r}99 \\
1\end{array}$ \\
\hline 3 & $\begin{array}{l}\text { Using the seeds of natural varieties, not } \\
\text { the result of genetic engineering / } \\
\text { modification. }\end{array}$ & $\begin{array}{l}\text { a. Know } \\
\text { b. Do not know }\end{array}$ & $\begin{array}{l}51 \\
19\end{array}$ & $\begin{array}{l}73 \\
27\end{array}$ \\
\hline 4 & $\begin{array}{l}\text { Control of pests and diseases using } \\
\text { organic pesticides }\end{array}$ & $\begin{array}{l}\text { a. Know } \\
\text { b. Do not know }\end{array}$ & $\begin{array}{r}65 \\
5\end{array}$ & $\begin{array}{r}93 \\
7\end{array}$ \\
\hline 5 & $\begin{array}{l}\text { Land and irrigation water sources for } \\
\text { organic farming should be separated } \\
\text { from conventional farming }\end{array}$ & $\begin{array}{l}\text { a. Know } \\
\text { b. Do not know }\end{array}$ & $\begin{array}{r}61 \\
9\end{array}$ & $\begin{array}{l}87 \\
13\end{array}$ \\
\hline
\end{tabular}

Table 2. Farmers' Assessment of Organic Farming Practices

\begin{tabular}{|c|c|c|c|c|}
\hline & Main Indicators & Answer & Amount & Percent \\
\hline \multirow{5}{*}{1} & \multirow{5}{*}{ Organic farming practices } & 1. Very easy & 1 & 1 \\
\hline & & 2. Easy & 20 & 29 \\
\hline & & 3. Ordinary course & 29 & 41 \\
\hline & & 4. Difficult & 18 & 26 \\
\hline & & 5. Very difficult & 2 & 3 \\
\hline \multirow{5}{*}{2} & \multirow{5}{*}{$\begin{array}{l}\text { Farmland must be converted from } \\
\text { non-organic to organic land without } \\
\text { contaminated by synthetic } \\
\text { chemicals for } 2-3 \text { years }\end{array}$} & 1. Very easy & 0 & 0 \\
\hline & & 2. Easy & 4 & 6 \\
\hline & & 3. Ordinary course & 18 & 26 \\
\hline & & 4. Difficult & 31 & 44 \\
\hline & & 5. Very difficult & 17 & 24 \\
\hline \multirow{5}{*}{3} & \multirow{5}{*}{$\begin{array}{l}\text { The process of obtaining and } \\
\text { transporting organic fertilizer to the } \\
\text { fields / gardens / rice fields } \\
\text { regularly every season }\end{array}$} & 1. Very easy & 3 & 4 \\
\hline & & 2. Easy & 35 & 50 \\
\hline & & 3. Ordinary course & 19 & 27 \\
\hline & & 4. Difficult & 11 & 16 \\
\hline & & 5. Very difficult & 2 & 3 \\
\hline \multirow{5}{*}{4} & \multirow{5}{*}{$\begin{array}{l}\text { The price of purchasing seeds of } \\
\text { natural varieties - bnot the result of } \\
\text { engineering / modification of } \\
\text { genetics. }\end{array}$} & 1. Very easy & 2 & 3 \\
\hline & & 2. Easy & 15 & 21 \\
\hline & & 3. Ordinary course & 35 & 50 \\
\hline & & 4. Difficult & 14 & 20 \\
\hline & & 5. Very difficult & 4 & 6 \\
\hline \multirow{5}{*}{5} & \multirow{5}{*}{$\begin{array}{l}\text { Control of pests and diseases using } \\
\text { organic pesticides }\end{array}$} & 1. Very easy & 1 & 1 \\
\hline & & 2. Easy & 14 & 20 \\
\hline & & 3. Ordinary course & 17 & 24 \\
\hline & & 4. Difficult & 33 & 47 \\
\hline & & 5. Very difficult & 5 & 7 \\
\hline \multirow{5}{*}{6} & \multirow{5}{*}{$\begin{array}{l}\text { Land and irrigation water sources } \\
\text { for organic farming should be } \\
\text { separated from conventional } \\
\text { farming }\end{array}$} & 1. Very easy & 0 & 0 \\
\hline & & 2. Easy & 25 & 36 \\
\hline & & 3. Ordinary course & 6 & 9 \\
\hline & & 4. Difficult & 25 & 36 \\
\hline & & 5. Very difficult & 14 & 20 \\
\hline
\end{tabular}




\section{Farmers' Assessment of Organic Farming Practices}

Farmers' assessment of the complexity of organic farming practices is also important because it can be one of the reasons why organic farming practices are not widely adopted by farmers in the region. Nevertheless, there are still other possible reasons why organic farming practices have not been developed among farmers, such as the socioeconomic characteristics of farmers, like education level, farmer status, and livestock ownership. The assessment on Bondowoso Regency farmers on organic farming practices is presented in Table 2.

The idea that the agricultural land must be converted from non-organic soil to organic without being pollutedbysynthetic chemicals for 2-3 years is considered to require a long time by 31 (44\%) farmers and very long by $17(24 \%)$ farmers. In this case, organic farming is considered to be more difficult to do than land-use practices on conventional farming. So, farmers must be patient to wait until farmland and the harvest can be called organic.

The use of organic fertilizer is considered easy by 35 $(50 \%)$ organic farmers because they are already accustomed to making their own organic fertilizer and the availability of organic fertilizer is also very abundant in the environment around them. Organic fertilizers commonly used in organic farming are: manure, liquid fertilizer, compost fertilizer and green manure. The most important thing for organic farmers is tenacity and patience because organic fertilizers are different from synthetic chemical fertilizers that are ready to use. Organic farmers consider that the practice of using organic fertilizers is not more difficult than the practice of using synthetic chemical fertilizers although the availability of organic fertilizers in quantity is more than that of synthetic fertilizers.

The use of native (local) varieties of seeds is considered normal or there is no difference in the level of complexity when compared to the practice of using hybrid varieties of seeds on conventional farming. A total of $35(50 \%)$ of farmers declared the price of organic seeds is normal (not different) with the seeds commonly used by conventional farmers. This is because the price of local seeds used is almost the same as that of hybrid seeds. Even if the price is different, the price difference between the seeds of local varieties and hybrids is not that big. In addition, technically the seedling of local varieties is the same as hybrid varieties.

Control of plant pests and diseases using organic pesticides is considered more difficult than controlling plant pests and diseases by using synthetic chemical pesticides by $33(47 \%)$ farmers. According to farmers, the use of organic pesticides should be more often done, both for prevention and eradication of pests and diseases, especially if there is a pest attack. Organic pesticides are considered less effective by farmers than manufactured chemical pesticides. Synthetic chemical pesticides are ready for use, more practical, and the amount of use is not much in a season. In addition, the process to make organic pesticides was considered quite complicated, although the raw material is available in the environment.

Irrigation land and irrigation sources for organic farming should be separated from conventional farming is considered more difficult than land and irrigation water sources for conventional farming that should not be separated with other farming systems. A total of $39(56 \%)$ of all farmers found it difficult and very difficult to separate land and irrigation sources from those from conventional farming. Farmers claim to have difficulty in avoiding pollution of synthetic chemicals from the land and irrigation water sources around them, due to too much agricultural land and irrigation water sources for conventional farming. Thus, organic farming requires very careful treatment and must be isolated from any contamination of synthetic chemicals.

In general, 29 (41\%) of farmers and $20(29 \%)$ of farmers stated that organic farming practices are common and easy to implement, while $18(26 \%)$ of farmers say it difficult. The results of the research is in accordance with the findings of Widiarta et al. [6] that there is a significant difference between the level of complexity of organic and conventional farming practices according to farmers' perceptions. Three indicators that are still difficult for farmers are land conversion, organic fertilizer and pesticide use, and irrigation sources.

\section{CONCLUSION}

The results conclude that although most farmers have already had sufficient knowledge of organic farming systems, there is still difficulty in organic farming practices. This is one of the strong reasons why organic farming practices are not widely adopted by farmers.

\section{ACKNOWLEDGEMENTS}

The research was funded by the Ministry of Research, Technology, and Higher Education at the Institutions National Strategic Research Scheme in Fiscal Year 2018.

\section{REFERENCES}

[1] Nurhidayati, Istirochah Pujiwati, Anis Solichah, Djuhari, and Abd. Basit. 2008. Organic Farming, An Integrated and Sustainable Agricultural Systems Study. Malang: Faculty of Agriculture Islamic University of Malang.

[2] FAO. 1999. Organic Agriculture. Rome: Agriculture and Consumer Protection Department. http://www.fao.org/docrep/meeting/X0075e.htm (cited 31 April 2018).

[3] National Standardization Bureau. 2016. SNI 6729: 2016 on the Organic Farming System

[4] Sutanto, R. 2002. Application of Organic Agriculture Penitentiary and Development. Kanisius. Jakarta.

[5] Indah Prihartini and Sutawi. 2015. Research on the Impact of Cluster Formation (Case Study in Organic Rice Cluster of Banyuwangi Regency and Bondowoso Regency). Research Report, Cooperation between UMM and Bank Indonesia KPW Jember.

[6] Widiarta, A., Soeryo Adiwibowo, and Widodo. 2011. Sustainability Analysis of Organic Farm Practices among Farmers. Sodality: Transdisciplinary Journal of Sociology, Communication, and Human Ecology April 2011, p. 71-89 